\title{
AMBIENTAL IMPACTS CAUSED BY THE APPLICATION OF POULTRY SLAUGHTERHOUSE WASTEWATER ON SOILS
}

\author{
Impactos ambientais causados pela aplicação de efluentes de abatedouro de aves em solos
}

\author{
Augusto Vaghetti Luchese ${ }^{1 *}$, Alessandra Algeri², Paulo Cesar Conceição ${ }^{3}$, Alessandro Jefferson Sato ${ }^{4}$ \\ ${ }^{1}$ Prof. Adjunto do Departamento de Ciências Agronômicas da Universidade Federal do Paraná; (* autor para \\ correspondência), e-mail: aluchese@gmail.com \\ ${ }^{2}$ Mestranda do programa de Tecnologias em Bioprodutos Agroindustriais da Universidade Federal do Paraná (UFPR) Setor \\ Palotina; e-mail: sandra.algeri.utfpr@gmail.com \\ ${ }^{3}$ Professor do Programa de Pós-Graduação em Agronomia PPGAG da Universidade Tecnológica Federal do Paraná (UTFPR); e- \\ mail: paulocesar@utfpr.edu.br. \\ ${ }^{4}$ Prof. Adjunto do Departamento de Ciências Agronômicas da Universidade Federal do Paraná; e-mail: asato@ufpr.br
}

Artigo enviado em 15/02/2017, aceito em 12/04/2017 e publicado em 07/07/2017.

\begin{abstract}
Poultry slaughterhouses generate significant amounts of wastewater, therefore, for the slaughter of each bird about 15 liters of water are spent. The main characteristics of these effluents are the high organic load and concentration of nutrients, particularly nitrogen and phosphorus. An alternative to reduce treatment costs of this residue would be to use it directly within the soil. The nutrients present in the effluent can be used in agriculture to replace the synthetic commercial fertilizers. This trial aimed at evaluating the application of poultry raw effluent in a Oxisol and registered possible environmental impacts by ions leaching, in $10 \mathrm{x} 60 \mathrm{~cm}$ (diameter $\mathrm{x}$ height) PVC columns filled with $50 \mathrm{~cm}$ of soil. Four doses were applied with four replications in soil columns, which were defined according to nitrogen requirement regarding a $9.17 \mathrm{Mg} \mathrm{ha}^{-1}$ corn yield $(0,50,100,150$ and 200\%). In each column, there have been five $1.42 \mathrm{~L}$ water applications, which corresponded to the highest rainfall recorded in the region $(180.95 \mathrm{~mm}$ during a day). Ions of $\mathrm{Ca}, \mathrm{Mg}, \mathrm{K}$ and $\mathrm{P}$ leachate contents do not exceed the limits of water quality, established by CONAMA Resolution; while $\mathrm{N}$ contents extrapolated too much such conditions. The leaching analysis showed differences in the increment of $\mathrm{N}, \mathrm{K}$ and organic carbon in the upper layers $(0-20 \mathrm{~cm})$ in relation to the lowest ones $(20-50 \mathrm{~cm})$.
\end{abstract}

Keywords - soil columns, ions leaching, environmental impact.

RESUMO - Os frigoríficos de aves geram quantidade significativa de efluentes líquidos, pois, para o abate de cada ave são gastos aproximadamente 15 litros de água. As principais características desses efluentes são as elevada carga orgânica e concentração de nutrientes, principalmente nitrogênio e fósforo. Uma alternativa para reduzir custos de tratamento com esse resíduo seria utilizá-lo de maneira direta no solo. Os nutrientes presentes no efluente podem ser utilizados na agricultura para que substituam os fertilizantes comerciais sintéticos. O presente experimento, com o objetivo de avaliar a aplicação de efluente bruto de frigorífico de frango em um Latossolo Vermelho, observou os possíveis impactos ambientais pela lixiviação de íns, a partir da montagem de colunas em PVC de $10 \mathrm{x} 60 \mathrm{~cm}$ (diâmetro x altura), preenchidas com $50 \mathrm{~cm}$ de solo. Nas colunas de solo, foram aplicadas quatro doses, com quatro repetições, as quais foram definidas segundo a necessidade de nitrogênio para produtividade de $9,17 \mathrm{Mg} \mathrm{ha}^{-1}$ de milho $(0,50,100,150$ e 200\%). Em cada coluna, foram feitas cinco aplicações de água de 1,42 L, que corresponderam à maior precipitação registrada na região $(180,95 \mathrm{~mm}$ no dia). Os teores dos íons $\mathrm{Ca}, \mathrm{Mg}$, K e P lixiviados não ultrapassam os limites de qualidade de água, estabelecidos pela resolução do CONAMA; enquanto os teores de $\mathrm{N}$ extrapolaram muito tais condições. A análise de percolação apontou diferenças no incremento de N, K e Carbono Orgânico nas camadas superiores $(0-20 \mathrm{~cm})$ em relação às camadas inferiores $(20-50 \mathrm{~cm})$.

Palavras-chave - colunas de solo, lixiviação de íons, impacto ambiental.

\section{INTRODUCTION}

Waste generation occurs throughout the production process and the biggest problem associated with this fact is the cost of the employed treatment processes so that the waste does not cause negative impacts on the environment. Liquid effluents deserve special attention, since the spread of this type of waste is faster, and the main destination of pollutants and contaminants in wastewater are surface or groundwater sources. 
Poultry slaughterhouses generate significant amounts of wastewater, therefore, for the slaughter of each bird about 15 liters of water are spent (MENEGAZ et al., 2011). The main characteristics of these effluents are the high organic load and concentration of nutrients, particularly nitrogen and phosphorus (PINTO et al., 2015).

According to data from IBGE, in 2014, 5.6 billion chickens were slaughtered in Brazil. The South region accounted for about $60 \%$ of the national poultry slaughter with the state of Paraná leading the national ranking, with approximately $28 \%$ of all birds slaughtered in the country. Thus, it can be inferred that, in 2014, about 84 million cubic meters of poultry slaughterhouse wastewater were generated in Brazil.

An alternative to reduce treatment costs of this residue would be to use it directly within the soil. The nutrients present in the effluent can be used in agriculture to replace the synthetic commercial fertilizers (SANTOS et al., 2010; CHENG; CHU, 2011). The disposal of residual animal water in the soil is widely used in the world, mainly in Europe and the United States, both as a treatment technique for surface runoff and for the fertilization of cultivated soils (FREITAS et al., 2004).

The reuse of residual water in agriculture is an important factor from the point of view of water management. The soil itself can act as a great debugging agent of pollutants contained in the effluents; acting similarly to a filter and provides water for plants and nutrients that are important to their development (BERTONCINI, 2008).

The element retention capacity varies according to the type of soil (BAME et al., 2013). The factors that determine the soil ion mobility are the texture, porosity and characteristic of each colloidal surface that influence the solubility and ion exchange for adsorption-desorption processes (SILVA; GRIEBELER; BORGES, 2007; FERREIRA et al. , 2006).

In general, the dynamics of ions in the soil has a higher concentration of these in the superficial layers, and with an increase in depth, a CTC reduction occurs thereby reducing the concentration of ions in the soil due to the reduced ability of these layers to promote ion exchanges. However, there are different dynamics related to the mobility of ions in the soil because, on one hand, some ions have low mobility and other elements have high mobility and reach considerable depths easily, consequently hindering cycling in the middle and thus leave the soil system.

One needs to be careful and have prior knowledge of the type of soil if the effluents are to be used directly on the ground so that there is no pollution of water resources, which occurs by rainwater percolation in soil layers, resulting in leaching of ions. Various studies have been developed with the application of organic waste, for assessing the risk of pollution and environmental contamination by leaching of ions.

Based on the results in the literature, different distinct behaviors were recorded: some ions that may or may not exhibit leaching losses, ions that are problematic because they have large losses and even those who practically do not have significant losses. Anami et al. (2008) evaluated the leaching of nitrate and phosphate ions in soil columns, whose results that had a higher tendency as to the mobility of nitrate ions and a low risk of contamination were presented by phosphate ion.

Within the groups that present or not leaching losses in the literature, when there is a application of wastewater to the soil under different conditions, ions were found such as $\mathrm{Ca}^{2+}, \mathrm{Mg}^{2+}$ and $\mathrm{K}^{+}$as observed by Correa et al, (2007); Donagemma et al. (2008) and Luchese et al. (2008), but these losses have not always been verified (CAOVILLA et al, 2010; BAME et al, 2013). In the group of ions with worrying potential polluter is the nitrate ion, which always show high losses (CORREA et al., 2007, ANAMI al, 2008; DONAGEMMA et al, 2008; LUCHESE et al, 2008; CHENG; CHU, 2011; BAME et al, 2013).

Finally, the group of ions considered not as worrying is phosphate which is characterized by its low leaching, when measured in Brazilian soils and has shown no potential polluter by the application of wastewater (ANAMI et al, 2008; DONAGEMMA et al, 2008; LUCHESE et al, 2008; CAOVILLA et al, 2010; BAME et al, 2013).

The leaching of ions accelerates the water eutrophication process and reduces the quality of the groundwater used for gathering water for animals, irrigation and even for human consumption. Given the above, the objective of this study was to evaluate the environmental impact caused by the leakage of ions, when applied to a specific amount of effluent from a poultry slaughterhouse in soil columns filled with Oxisol.

\section{METHODOLOGY}

This study was conducted at the laboratory of the Engenharia Ambiental da Faculdade Educacional de Dois Vizinhos - FAED / União de Ensino do Sudoeste do Paraná - UNISEP, campus Dois Vizinhos-PR. Thus, to determine the effect of direct disposal of poultry abattoirs residues in the soil, in the contamination of subsurface water, an experiment was set up in leaching columns.

The experiment was developed from a factorial design model 5 x 5 with 4 repetitions. 20 PVC tubes 60 $\mathrm{cm}$ high and $10 \mathrm{~cm}$ in diameter were used, with a shut perforated end, adapting it to pick up the leached material. All tubes were filled with $50 \mathrm{~cm}$ of soil 
respecting the layers, where five water pulses were applied with intervals of seven days.

The soil was the Oxisol, collected in the municipality of Itapejara D'Oeste, PR. The samples collected in the field were separated at depths of 0-20 $\mathrm{cm}$ and $20-50 \mathrm{~cm}$ of the soil profile. After removal, the samples were air dried and passed through a sieve with apertures of $2 \mathrm{~mm}$. The chemical and physical characteristics of the soil are given in Tables 1 and 2, respectively.

The readings of $\mathrm{pH}_{\mathrm{CaCl} 2}, \mathrm{pH}_{\mathrm{SMP}}, \mathrm{Ca}^{2+}, \mathrm{Mg}^{2+}$, $\mathrm{Al}^{+3}$ and $\mathrm{K}^{+}$of the soil were made according to the recommendations by EMBRAPA (2011). The determination of $\mathrm{P}$ was obtained according to Malavolta et al. (1997) and soil texture was determined by the pipette method with total dispersion according to EMBRAPA (1997).

The effluent used for the analysis was collected at the entrance of the first treatment system, still in a raw state, in a poultry slaughterhouse within the city of Itapejara D'Oeste PR. The chemical characteristics of the effluent under study are presented in Table 3 as well as the measurements of $\mathrm{Ca}^{2+}, \mathrm{Mg}^{2+}, \mathrm{K}^{+}$and organic matter (EMBRAPA, 2011). The $\mathrm{PO}_{4}{ }^{3-}$ and total nitrogen were measured according to the methodology described by Malavolta et al. (1997). The $\mathrm{pH}$ was determined in the crude extract of waste after being stirred for 10 minutes and filtered.

According to COELHO (2007), to obtain a productivity of $9.17 \mathrm{t} \mathrm{ha}^{-1}$ of corn, $187 \mathrm{~kg} \mathrm{ha}^{-1}$ of nitrogen is required. The residue used had $1.925 \mathrm{~g} \mathrm{~L}^{-1}$ of total $\mathrm{N}$. Thus, to the area of the tube, $76.36 \mathrm{~mL}$ of residue was used as the optimal dose equivalent to a dose of $187 \mathrm{~kg} \mathrm{ha}^{-1}$ required to obtain the productivity. The four doses applied directly to the pipe surface were half a dose- $50 \%$ (38.18 mL), one dose 100\% (76.36 mL), one dose and a half $150 \%(114.54 \mathrm{~mL})$ and two doses, $200 \%$ $(152.72 \mathrm{~mL})$, with a control-treatment of $0 \%$.

Table 1. Soil chemical characteristics before the leaching tests

\begin{tabular}{ccccccccc}
\hline Soil layer & \multicolumn{2}{c}{$\mathrm{pH}$} & $\mathrm{Al}^{+3}$ & $\mathrm{H}^{+} \mathrm{Al}$ & $\mathrm{Ca}^{2+}$ & $\mathrm{Mg}^{2+}$ & $\mathrm{K}^{+}$ & $\mathrm{P}$ \\
\hline $\mathrm{cm}$ & $\mathrm{CaCl}_{2}$ & $\mathrm{SMP}$ & & & $\mathrm{cmol}_{\mathrm{c}} \mathrm{dm}^{-3}$ & & & $\mathrm{mg} \mathrm{L}^{-1}$ \\
\hline $0-20$ & 5.72 & 6.27 & 0.0 & 3.18 & 7.8 & 3.9 & 0.14 & 7.46 \\
$20-50$ & 5.42 & 6.44 & 0.0 & 2.66 & 4.4 & 1.1 & 0.08 & 1.81 \\
\hline
\end{tabular}

Table 2. Soil granulometric analysis

\begin{tabular}{cccc}
\hline \multirow{2}{*}{$\begin{array}{c}\text { Soil layer } \\
\text { Cm }\end{array}$} & Sand & Granulometric analysis & Clay \\
\cline { 2 - 4 } & \multicolumn{3}{c}{ Silt } \\
\hline $0-20$ & 331.4 & $\mathrm{~g} \mathrm{~kg}^{-1}$ & 369.0 \\
\hline $20-50$ & 356.4 & 299.6 & 366.6 \\
\hline
\end{tabular}

Table 3. Chemical characteristics of the effluent used in tests

\begin{tabular}{ccccccc}
\hline $\mathrm{pH}$ & $\mathrm{MO}$ & $\mathrm{TN}$ & $\mathrm{Ca}^{2+}$ & $\mathrm{Mg}^{2+}$ & $\mathrm{K}^{+}$ & $\mathrm{PO}_{4^{3-}}$ \\
\hline $\mathrm{H}_{2} \mathrm{O}$ & $\mathrm{g} \mathrm{L}^{-1}$ & $\mathrm{~g} \mathrm{~L}^{-1}$ & & & $\mathrm{mg} \mathrm{L}^{-1}$ & \\
\hline 6.48 & 144.8 & 1.925 & 8.02 & 2.03 & 0.62 & 0.28 \\
\hline
\end{tabular}

The historical measures from Paraná Agronomic Institute (Instituto Agronômico do Paraná) (IAPAR 2016a, IAPAR 2016b) were used to estimate the volume of water to the water pulses the average of the highest rainfall in 24 hours recorded in the municipality of Francisco Beltrão and Pato Branco, which were $183.6 \mathrm{~mm}$ and $178.3 \mathrm{~mm}$, respectively. From the average of the two precipitations, the volume calculated and used in all tubes was 1.420 liters of water per pulse. While the maximum water-holding capacity of the soil columns was determined gravimetrically and found that each soil column could hold 1.6 L of water.

The columns were mounted respecting the soil depths. The effluent was applied to the columns directly over the top and then immediately had distilled/deionized water applied until dripping had initiated, which was sufficient to saturate the pores. At the end of the application of water pulses, they collected the leached extracts of all columns and these were removed for a seepage analysis.

The extracts of all the tubes underwent analysis to determine the concentration level of calcium, magnesium, potassium and phosphate, mineral nitrogen and $\mathrm{pH}$. The samples of calcium, magnesium and potassium were determined according to the EMBRAPA methodology (2011). The phosphate and mineral nitrogen were determined according to Malavolta et al., (1997) and $\mathrm{pH}$ was obtained by direct reading on the $\mathrm{pH}$ meter.

To obtain the percolation data, column samples were taken after five pulses of water at every 10 $\mathrm{cm}$, and separated samples of $0-10,10-20,20-30,30-40$ and $40-50 \mathrm{~cm}$ deep, totaling 100 samples. 
The soil samples were analyzed for the determination of both nutrients that have greater movement of soil characteristics: total mineral nitrogen and potassium. Also the determination of organic carbon was carried out by presenting a great influence on the movement of ions in the soil. All soil analyzes were carried out following the methodology described by EMBRAPA (2011).

The data obtained from the analysis of the extracts were subjected to analysis of variance, while the doses and pulses were assessed by regression, by the SAEG program. The results of percolation tests were submitted to analysis of variance. After ANOVA, differences between treatments were performed by Tukey test $(p<0.05)$ to the depths, and the doses were assessed by a regression analysis.

\section{RESULTS AND DISCUSSION}

The results presented in Table 4 show the total amount of applied Nitrogen, Phosphorus, Calcium, Magnesium and Potassium in each dose, serving as a quantitative parameter of the applied elements in each column. Thus, it was possible to see that $\mathrm{N}$ is the element most applied by the doses of residue.

Table 4. Amount of nutrients applied as affected by effluent doses in soil columns

\begin{tabular}{cccccc}
\hline $\begin{array}{c}\text { Doses } \\
(\%)\end{array}$ & $\mathrm{TN}$ & $\mathrm{P}$ & $\mathrm{K}^{+}$ & $\mathrm{Mg}^{2+}$ & $\mathrm{Ca}^{2+}$ \\
\cline { 2 - 6 } & $\mathrm{g}$ & $---------------m g---------------$ \\
\hline 50 & 0.073 & 0.003 & 0.024 & 0.077 & 0.306 \\
100 & 0.147 & 0.007 & 0.047 & 0.155 & 0.612 \\
150 & 0.220 & 0.010 & 0.071 & 0.233 & 0.918 \\
200 & 0.294 & 0.014 & 0.095 & 0.310 & 1.224 \\
\hline
\end{tabular}

\section{pH}

The regression analysis showed that there is no significant relationship between the $\mathrm{pH}$ value of the leached extract and the applied residue doses. But, compared to the values found, it was discovered that the first pulse showed lower $\mathrm{pH}$ values with average values of 5.28 . While the other pulses showed average values always higher than 6.2 (Table 5).

This situation is expected due to high humidity conditions given the residue and water application, with the discontinuation of the soil at the base of the column, which favors the accumulation of water in the region, possibly causing the occurrence of reducing conditions in the sifted aggregates, developing an increase in the $\mathrm{pH}$ of the leached solution (SPOSITO, 2008), as has been observed in other papers of leaching in columns (LUCHESE et al., 2008).

The $\mathrm{pH}$ values of the control treatments also increased after the second dose and according to the leached soil values who received treatment, this $\mathrm{pH}$ behavior in the control was also observed in the study by Luchese et al. (2008).

Table 5. $\mathrm{pH}$ values of the water leached from soil columns as affected by effluent doses and water pulses applied

\begin{tabular}{|c|c|c|c|c|c|}
\hline \multirow[b]{2}{*}{ Doses $(\%)$} & \multicolumn{5}{|c|}{$\mathrm{pH}$} \\
\hline & $\begin{array}{c}\text { Pulse } \\
1\end{array}$ & $\begin{array}{c}\text { Pulse } \\
2\end{array}$ & $\begin{array}{c}\text { Pulse } \\
3\end{array}$ & $\begin{array}{c}\text { Pulse } \\
4\end{array}$ & $\begin{array}{c}\text { Pulse } \\
5\end{array}$ \\
\hline 0 & 5.52 & 6.74 & 6.35 & 6.37 & 6.26 \\
\hline 50 & 5.38 & 6.66 & 6.35 & 6.34 & 6.32 \\
\hline 100 & 5.13 & 6.63 & 6.01 & 6.36 & 6.31 \\
\hline 150 & 5.30 & 6.60 & 6.19 & 6.28 & 6.25 \\
\hline 200 & 5.055 & 6.63 & 6.21 & 6.24 & 6.25 \\
\hline $\begin{array}{l}\text { Regression } \\
\quad(\mathrm{y}=\overline{\mathrm{y}})^{\mathrm{ns}}\end{array}$ & 5.28 & 6.65 & 6.22 & 6.32 & 6.28 \\
\hline
\end{tabular}

\section{Calcium and Magnesium}

Regarding the $\mathrm{Ca}^{2+}$ and $\mathrm{Mg}^{2+}$, there was also no significant ratio between the concentration of these ions in the leachate and the residue levels applied in this study (Table 6). Most leaching occurred on the 1st pulse, but the levels decreased at every water pulse applied.

Ordinance 2,914, of December 12, 2011, which dispose about water quality and potability standards, allows maximum hardness of $500 \mathrm{mg} \mathrm{L}^{-1}$. Total hardness is caused by calcium and magnesium ions, both expressed in calcium carbonate concentration $\mathrm{CaCO}_{3} \mathrm{mg} \mathrm{L}^{-1}$.

The $\mathrm{Ca}^{2+}$ and $\mathrm{Mg}^{2+}$ content analysis were between $35.05 \mathrm{mg} \mathrm{L}^{-1}$ and $6.00 \mathrm{mg} \mathrm{L}^{-1} \mathrm{Ca}^{2+}$ and between $0.42 \mathrm{mg} \mathrm{L}^{-1}$ and $0.079 \mathrm{mg} \mathrm{L}^{-1}$ of $\mathrm{Mg}^{2+}$. This data corresponds to a total hardness of between $89.26 \mathrm{mg}$ $\mathrm{CaCO}_{3} \mathrm{~L}^{-1}$ and $15.28 \mathrm{mg} \mathrm{CaCO}_{3} \mathrm{~L}^{-1}$, ie they are within the recommended limits (ORDINANCE, 2914). It can also be seen that the doses did not interfere in the content of leached $\mathrm{Ca}^{2+}$ and $\mathrm{Mg}^{2+}$ because the contents of the control analyzes (zero dose) were within the overall average.

The losses of $\mathrm{Ca}^{2+}$ and $\mathrm{Mg}^{2+}$ in the soils are generally low in relation to other elements (BAME et al, 2013;. CAOVILLA et al., 2010). This is due to the fact that these ions present certain affinity for colloids according to their charges and ionic radius, which are retained in preference to other elements, such as $\mathrm{K}^{+}$and $\mathrm{Na}^{+}$(SPOSITO, 2008). 
Table 6. Calcium and magnesium leached from soil columns as affected by effluent doses and water pulses applied

\begin{tabular}{|c|c|c|c|c|c|}
\hline \multirow{2}{*}{ Doses $(\%)$} & \multicolumn{5}{|c|}{ Magnesium (mg L-1) } \\
\hline & Pulse 1 & Pulse 2 & Pulse 3 & Pulse 4 & Pulse 5 \\
\hline 0 & 0.426 & 0.170 & 0.091 & 0.097 & 0.079 \\
\hline 50 & 0.414 & 0.170 & 0.103 & 0.097 & 0.073 \\
\hline 100 & 0.390 & 0.170 & 0.097 & 0.091 & 0.073 \\
\hline 150 & 0.390 & 0.170 & 0.103 & 0.085 & 0.073 \\
\hline 200 & 0.341 & 0.164 & 0.110 & 0.091 & 0.073 \\
\hline \multirow[t]{2}{*}{$\begin{array}{l}\text { Regression } \\
(y=\bar{y})^{n s}\end{array}$} & 0.392 & 0.169 & 0.101 & 0.092 & 0.074 \\
\hline & \multicolumn{5}{|c|}{ Calcium (mg. $\left.\mathrm{L}^{-1}\right)$} \\
\hline 0 & 35.052 & 14.021 & 7.511 & 8.012 & 6.510 \\
\hline 50 & 34.051 & 14.021 & 8.513 & 8.012 & 6.009 \\
\hline 100 & 32.048 & 14.021 & 8.012 & 7.511 & 6.009 \\
\hline 150 & 32.048 & 14.021 & 8.513 & 7.010 & 6.009 \\
\hline 200 & 28.042 & 13.520 & 9.013 & 7.511 & 6.009 \\
\hline $\begin{array}{c}\text { Regression } \\
(\mathrm{y}=\overline{\mathrm{y}})^{\mathrm{ns}}\end{array}$ & 32.248 & 13.921 & 8.312 & 7.611 & 6.109 \\
\hline
\end{tabular}

ns - not significant at a probability level of $5 \%$

\section{Potassium}

The potassium ion $\left(\mathrm{K}^{+}\right)$and other evaluated ions, showed no significant ratio between the concentration of this ion in the extract and the residue levels applied, according to the regression analysis. However, $\mathrm{Ca}^{2+}$ and $\mathrm{Mg}^{2+}$ ions showed the highest levels, the same doesn't occurred with $\mathrm{K}$, which were recorded on the first pulse, getting between $0.33 \mathrm{mg} \mathrm{L}^{-1}$ and $0.40 \mathrm{mg} \mathrm{L}^{-1}$. On pulse 2 , it can be noted that there was greater retention of $\mathrm{K}^{+}$in the treated soils, if compared to the control, the leachate treatments showed concentrations between $0.47 \mathrm{mg} \mathrm{L}^{-1}$ and 0.36 $\mathrm{mg} \mathrm{L} \mathrm{L}^{-1}$, and the leached of the control, $0.52 \mathrm{mg} \mathrm{L}^{-1}$ (Table 7). The greater retention of $\mathrm{K}^{+}$in the treated soil was also observed by Luchese et al. (2008), Donagemma et al. (2008) and Caovilla et al. (2010).

In pulses 3, the averages of the levels of leaching with treatment are lower than the average of the control treatments. Sposito (2008) claims that the retention of $\mathrm{K}^{+}$is due to the formation of inner-sphere complexes with clay minerals $2: 1$. Thus, the ionic radius of $\mathrm{K}^{+}$contributes to the retention of the element in the soil. However, oxisol has small amounts of this mineral type; therefore, a faster leaching is expected of this ion than the others.

The overall $\mathrm{K}^{+}$average was leached from 0.33 $\mathrm{mg} \mathrm{L}^{-1}$ and $0.57 \mathrm{mg} \mathrm{L}^{-1}$ and showed no pollution risks since potassium is an essential element for humans, whose recommended daily dose is higher than $3000 \mathrm{mg}$ (WHO, 2011).

Table 7. Content of potassium leached from soil columns as affected by effluent doses and water pulses applied

\begin{tabular}{c|c|c|c|c|c}
\hline \multirow{2}{*}{ Doses (\%) } & \multicolumn{5}{|c}{ Potassium (mg L-1) } \\
\cline { 2 - 6 } & Pulse 1 & Pulse 2 & Pulse 3 & Pulse 4 & Pulse 5 \\
\hline 0 & 0.520 & 0.520 & 0.520 & 0.520 & 0.520 \\
50 & 0.402 & 0.478 & 0.555 & 0.685 & 0.678 \\
100 & 0.332 & 0.408 & 0.390 & 0.515 & 0.520 \\
150 & 0.348 & 0.405 & 0.448 & 0.528 & 0.528 \\
200 & 0.355 & 0.360 & 0.410 & 0.538 & 0.530 \\
\hline $\begin{array}{c}\text { Regression } \\
(y=\bar{y}){ }^{\text {ns }}\end{array}$ & 0.356 & 0.434 & 0.464 & 0.568 & 0.548 \\
\hline ns - not significant at a probability level of 5\%
\end{tabular}

ns - not significant at a probability level of $5 \%$

\section{Phosphorus}

The regression analysis for phosphorus showed no significant ratio between the content of this ion in the extract and the residue levels applied. Phosphorous was the least leached element, with very low levels (Table 8). Low phosphorus leaching levels were also found by Luchese et al. (2008) and Basso et al. (2005). Also according to Basso et al. (2005), the largest phosphorus loss is by runoff, not leaching.

Table 8. Contents of phosphorus leached from soil columns as affected by effluent doses and water pulses applied

\begin{tabular}{c|c|c|c|c|c}
\hline \multirow{2}{*}{ Doses (\%) } & \multicolumn{5}{|c}{ Phosphorus $\left(\mathrm{mg} \mathrm{L}^{-1}\right)$} \\
\cline { 2 - 6 } & $\begin{array}{c}\text { Pulse } \\
1\end{array}$ & $\begin{array}{c}\text { Pulse } \\
2\end{array}$ & $\begin{array}{c}\text { Pulse } \\
\text { Pulse }\end{array}$ & $\begin{array}{c}\text { Pulse } \\
5\end{array}$ \\
\hline 0 & 0.068 & 0.166 & 0.125 & 0.068 & 0.136 \\
50 & 0.057 & 0.114 & 0.136 & 0.091 & 0.170 \\
100 & 0.045 & 0.102 & 0.114 & 0.068 & 0.125 \\
150 & 0.045 & 0.136 & 0.102 & 0.091 & 0.136 \\
200 & 0.045 & 0.102 & 0.114 & 0.079 & 0.114 \\
\hline $\begin{array}{c}\text { Regression } \\
(\mathrm{y}=\overline{\mathrm{y}})^{\mathrm{ns}}\end{array}$ & 0.0477 & 0.124 & 0.118 & 0.079 & 0.1364 \\
\hline ns - not significant at a probability level of 5\%
\end{tabular}

Freshwater quality standards set by the CONAMA Resolution No. 357 from 17 of March 2005, for total phosphorus are: for class 1 , lentic environment $0.020 \mathrm{mg} \mathrm{L}^{-1}$, lotic environment $0.1 \mathrm{mg} \mathrm{L}^{-1}$ class 3, lentic environment $0.05 \mathrm{mg} \mathrm{L}^{-1}$ and lotic environment $0.15 \mathrm{mg}$ $\mathrm{L}^{-1}$.

As the leached phosphorus levels were between $0.045 \mathrm{mg} \mathrm{L}^{-1}$ and $0.17 \mathrm{mg} \mathrm{L}^{-1}$, the element shows no water contamination potential (Table 8). 
The low mobility of this anion, according to Sposito (2008), occurs by the formation of internal spheres complexes with oxides and hydroxides of iron, aluminum and covalent bonds with their surfaces, minerals found in large quantities in the soil used for the study. For this leaching test, we'd like to emphasize that the study was done with an extreme case of precipitation, and without influence of plants.

\section{Nitrogen}

Like the other elements, the regression analysis for the relationship between the nitrogen content in the leached residue and the applied dose was not significant. It can be seen in Table 9 that the leached nitrogen content decreased with each applied pulse, with the most leaching in pulses 1 and 2, showing large initial moving of nitrogen.

The leached nitrogen content in all tubes can be explained by the mineralization of the soils organic matter and also of organic matter present in the wastewater used in the treatment (Gomes, 2004). It should be noted that nitrogen has a more effective accumulation in the soil, in surface layers, in times of drought, and when there are heavy rains such as simulated in this study. The trend is that the highest levels of this nutrient are found in the deeper layers due to the leaching process (LUNA et al., 2013).
Table 9. Content of nitrogen leached from soil columns as affected by effluent doses and water pulses applied

\begin{tabular}{|c|c|c|c|c|c|}
\hline \multirow[b]{2}{*}{ Doses $(\%)$} & \multicolumn{5}{|c|}{ Nitrogen $\left(\mathrm{mg} \mathrm{L}^{-1}\right)$} \\
\hline & $\begin{array}{c}\text { Pulse } \\
1\end{array}$ & $\begin{array}{c}\text { Pulse } \\
2\end{array}$ & $\begin{array}{c}\text { Pulse } \\
3\end{array}$ & $\begin{array}{c}\text { Pulse } \\
4\end{array}$ & $\begin{array}{c}\text { Pulse } \\
5\end{array}$ \\
\hline 0 & 40.27 & 31.51 & 17.51 & 14.01 & 14.01 \\
\hline 50 & 33.27 & 24.51 & 17.51 & 17.51 & 10.50 \\
\hline 100 & 38.52 & 24.51 & 19.26 & 17.51 & 10.50 \\
\hline 150 & 42.02 & 35.02 & 21.01 & 14.01 & 12.26 \\
\hline 200 & 31.51 & 22.76 & 15.76 & 14.01 & 10.50 \\
\hline $\begin{array}{c}\text { Regression } \\
\quad(y=\bar{y})^{n s}\end{array}$ & 37.12 & 27.66 & 18.21 & 15.41 & 11.55 \\
\hline
\end{tabular}

The levels found were between $42.02 \mathrm{mg} \mathrm{L}^{-1}$ and $10.50 \mathrm{mg} \mathrm{L}^{-1}$. All values are above the established by the CONAMA Resolution No. 357 from March 17th of 2005, which determines the total nitrogen content for freshwaters in classes 1 and 2, maximum of $1.27 \mathrm{mg} \mathrm{L}^{-1}$ for lentic environments and $2.18 \mathrm{mg} \mathrm{L}^{-1}$ to lotic environments. They are also above the standards for groundwater which is $11 \mathrm{mg} \mathrm{L}^{-1}$ for Class 1 waters, according to the CONAMA Resolution No. 369 from April $3^{\text {rd }}$ of 2008.

However, it can be said that the high concentration of $\mathrm{N}$ leached is not only due to the residue applied, because the treatments without this application also had levels higher than those recommended by the legislation. According to Sampaio et al. (2010) and Cheng and Chu (2011), nitrogen has high mobility in the soil, a fact that coupled with the large amount of water applied in pulses explains the easy vertical movement of nitrogen in the columns.

\section{Phosphorus and Nitrogen Seepage}

From the variance analysis, it was determined that there was no significant interaction between the applied residue dose and the depth of the samples for any of the evaluations (N, K and COT). Thus, each factor behaved independently (Table 10), when these showed to be significant.

Table 10. Analysis of variance of nitrogen, potassium and organic carbon from soils treated with doses of raw effluent poultry slaughterhouse within the depths of the samples

\begin{tabular}{|c|c|c|c|c|c|c|}
\hline \multirow{2}{*}{ Source } & \multicolumn{2}{|c|}{$\mathrm{N}$} & \multicolumn{2}{|c|}{$\mathrm{K}$} & \multicolumn{2}{|c|}{ C } \\
\hline & $\mathrm{F}$ & P-value & $\mathrm{F}$ & P-value & $\mathrm{F}$ & P-value \\
\hline Depth & 6.96 & $0.000^{* *}$ & 33.42 & $0.000^{* *}$ & 10.55 & $0.000^{* *}$ \\
\hline Dose & 5.58 & $0.001 * *$ & 0.25 & 0.907 & 1.15 & 0.341 \\
\hline Repetition & 3.98 & $0.011^{*}$ & 0.36 & 0.780 & 3.16 & $0.030 *$ \\
\hline Dose x Depth & 1.44 & 0.149 & 0.64 & 0.838 & 0.358 & 0.988 \\
\hline
\end{tabular}

$* *$ Significant at a probability level of $1 \%$
$*$ Significant at a probability level of $5 \%$ 
Table 11. Means of soil total nitrogen, potassium and organic carbon as affected by effluent doses and soil depths

\begin{tabular}{|c|c|c|c|c|c|c|}
\hline \multirow{2}{*}{ Depths } & \multicolumn{5}{|c|}{ Doses } & \multirow{2}{*}{ Means Depth } \\
\hline & $0 \%$ & $50 \%$ & $100 \%$ & $150 \%$ & $200 \%$ & \\
\hline \multicolumn{7}{|c|}{ Total nitrogen $\left(\mathrm{mg} \mathrm{dm}^{-3}\right)$} \\
\hline $0-10 \mathrm{~cm}$ & 1450.47 & 1552.3 & 1400.57 & 1299.31 & 1574.20 & $1455.37 \mathrm{~A}$ \\
\hline $10-20 \mathrm{~cm}$ & 1212.89 & 1511.98 & 1437.3 & 1314.88 & 1473.50 & $1390.10 \mathrm{~A}$ \\
\hline $20-30 \mathrm{~cm}$ & 1379.07 & 1436.86 & 1389.98 & 1098.04 & 1298.30 & $1320.46 \mathrm{AB}$ \\
\hline $30-40 \mathrm{~cm}$ & 989.67 & 1299.93 & 1371.00 & 1198.28 & 1087.60 & $1189.30 \mathrm{~B}$ \\
\hline $40-50 \mathrm{~cm}$ & 758.52 & 1276.49 & 1350.46 & 1187.21 & 1273.90 & $1169.31 \mathrm{~B}$ \\
\hline Mean & 1158.12 & 1415.51 & 1389.86 & 1219.54 & 1341.50 & $\mathrm{CV}(\%)=20.35$ \\
\hline \multirow{2}{*}{\multicolumn{7}{|c|}{$\mathrm{N}=1046+195.2 \mathrm{x}^{*}-29.68 \mathrm{x}^{2 *} \mathrm{R}^{2}=30,7^{*}$}} \\
\hline & & & & & & \\
\hline $0-10 \mathrm{~cm}$ & 0.09 & 0.09 & 0.1 & 0.1 & 0.08 & $0.093 \mathrm{~A}$ \\
\hline $10-20 \mathrm{~cm}$ & 0.09 & 0.1 & 0.09 & 0.09 & 0.08 & $0.088 \mathrm{~A}$ \\
\hline $20-30 \mathrm{~cm}$ & 0.07 & 0.06 & 0.08 & 0.07 & 0.07 & $0.070 \mathrm{~B}$ \\
\hline $30-40 \mathrm{~cm}$ & 0.05 & 0.05 & 0.05 & 0.05 & 0.06 & $0.051 \mathrm{C}$ \\
\hline $40-50 \mathrm{~cm}$ & 0.05 & 0.05 & 0.05 & 0.05 & 0.06 & $0.052 \mathrm{C}$ \\
\hline Mean & 0.07 & 0.07 & 0.074 & 0.072 & 0.07 & $\mathrm{CV}(\%)=31.44$ \\
\hline \multirow{2}{*}{\multicolumn{7}{|c|}{$\mathrm{K}=0.0653+0.00452 \mathrm{x}^{(\mathrm{ns})}-0.00074 \mathrm{x}^{2(\mathrm{~ns})} \mathrm{R}^{2}=0.003^{(\mathrm{ns})}$}} \\
\hline & & & & & & \\
\hline $0-10 \mathrm{~cm}$ & 1.44 & 1.52 & 1.50 & 1.52 & 1.45 & $1.48 \mathrm{~A}$ \\
\hline $10-20 \mathrm{~cm}$ & 1.42 & 1.50 & 1.54 & 1.45 & 1.46 & $1.47 \mathrm{~A}$ \\
\hline $20-30 \mathrm{~cm}$ & 1.37 & 1.38 & 1.34 & 1.22 & 1.35 & $1.33 \mathrm{~B}$ \\
\hline $30-40 \mathrm{~cm}$ & 1.24 & 1.30 & 1.25 & 1.22 & 1.32 & $1.27 \mathrm{~B}$ \\
\hline $40-50 \mathrm{~cm}$ & 1.26 & 1.32 & 1.32 & 1.23 & 1.37 & $1.30 \mathrm{~B}$ \\
\hline Mean & 1.35 & 1.40 & 1.39 & 1.33 & 1.39 & $\mathrm{CV}(\%)=19.90$ \\
\hline Regression & \multicolumn{5}{|c|}{$\mathrm{C}=1.350+0.0157 \mathrm{x}^{(\mathrm{ns})}-0.00236 \mathrm{x}^{2}(\mathrm{~ns}) \mathrm{R}^{2}=0.001^{(\mathrm{ns})}$} & \\
\hline
\end{tabular}

Means followed by the same letter in the column do not differ statistically from each other, $5 \%$ probability by Tukey test.

* Significant at a probability level of 5\%

ns - not significant at a probability level of $5 \%$

The assessment of the movement of the total nitrogen in soil columns although not presenting significant difference in the interaction dose/depth in an isolated way, showed significant responses based on the variance analysis (Table 11). With the analysis of the doses separately, held by regression, was observed whose regression models adjusted for the doses were significant, even with the low $\mathrm{R}^{2}$ value, showing sort of increment in total nitrogen with the increase of the dose (Table 11).

It appears that, in regard to the nitrogen content in depth, these significant differences where, statistically, the $0-20 \mathrm{~cm}$ layer has higher nitrogen concentration than the layer of $20-50 \mathrm{~cm}$. However, statistically one cannot conclude that there was enrichment in depth in nitrogen levels on soils that received the effluents. This process can easily be connected to the vertical moving as Nitrogen was also found in the leachate analysis.

Potassium is another ion that has easy handling in our soils; however, the low dosages used did not promote an increase in the levels of this element neither as a result of doses or of the depths measured (Table 11).

The only point where potassium showed statistically significant differences was in regard to 
depth, as indicated by ANOVA (Table 10). However, the decrease of potassium due to depth occurred in all treatments (Table 11), and there was no difference compared to the control. The amount of potassium residue was far below the concentration of NT (Table 4). Furthermore, the combined application of calcium and magnesium is higher than potassium and tends to favor the soil's potassium loss. Thus, potassium is leached and changes are not promoted in the concentrations, as calcium magnesium have higher filler concentration. These ions have a greater affinity for the soil exchange complex, with an emphasis on the soil used in the study that shows as dominant mineralogy, iron and aluminum oxides and kaolinite as silicate minerals.

The regression analysis (Table 11) confirms that the low doses used did not promote increments of potassium to the soils or the small increment promoted by the doses was completely lost because of high rainfall, to which the soil columns had been subjected.

The organic carbon had a similar behavior to $\mathrm{N}$ and $\mathrm{K}$ showed significant decrease with the increase in depth and had no variation in regard to the applied effluent doses (Table 11).

Since the organic carbon is a key factor both in the dynamics of $\mathrm{N}$ in the soil as well as the adsorption of cations, their amendment would have provided changes also in the remaining parameters. As this did not happen, all parameters showed the same behavior.

Thus, two assumptions are relevant: first - the applied dosages, which would provide significant amounts of $\mathrm{N}$ to the soil were not enough to promote major changes in the soils organic carbon and as a result, they were also not enough in the remaining parameters. The second assumption is that the organic matter applied, in which the organic carbon was contained, was rapidly degraded and the elements released by this, or that were already mineralized, were leached by large rainfall to which the soil columns were subjected.

\section{CONCLUSION}

The wastewater from the slaughterhouse has characteristics for application in the soil as a form of nutrient enrichment. The application of waste did not cause high losses increments of any of the evaluated elements since the doses differ only for nitrogen from the control.

Of the evaluated ions, only nitrogen was shown as potentially polluting, since the leachate analysis extrapolated the limits established by CONAMA. However, such pollution would occur even without the application of the waste, because the amount of simulated rainfall was high, corresponding to intense rainfall, a fact proven by leaching occurred in the control treatment.
The application of the crude effluent from poultry slaughterhouse in the soil is a possible destination for such residue, which brings advantages such as the reduction of treatment costs and the increment of value for the same. This can be used as agricultural fertilizer, provided that care is taken with certain criteria, such as possible existing pathogens in the effluent, which were not the subject of the study.

\section{REFERENCES}

ANAMI, M. H.; SAMPAIO, S. C.; SUSZEK, M.; GOMES, S. D.; QUEIROZ, M. M. F. Deslocamento miscível de nitrato e fosfato proveniente de água residuária da suinocultura em colunas de solo. Revista Brasileira de Engenharia Agricola e Ambiental. V. 12, n. 1, 2008.

BAME, I.B.; HUGHES, J.C.; TITSHALL, L.W.; BUCKLEY, C.A. Leachate characteristics as influenced by application of anaerobic baffled reactor effluent to three soils: a soil column study. Chemosphere, v. 93, p. 2171-2179, 2013.

BASSO, C. J.; CERETTA, C. A.; DURIGON, R.; POLETTO, N.; GIROT'TO, E. Dejeto líquido de suínos: II - perdas de nitrogênio e fósforo por percolação no solo sob plantio direto. Revista Ciência Rural, v.35, n.6, p. 1305-1312, 2005.

BERTONCINI, E. I. Tratamento de efluentes e reúso da água no meio agrícola. Revista Tecnologia \& Inovação Agropecuária, v.1, pp. 152-169, 2008.

CAOVILLA, F. A; SAMPAIO, S. C.; SMANHOTTO, A.; NÓBREGA, L. H. P.; QUEIROZ, M. M. F.; GOMES, B. M. Características químicas de solo cultivado com soja e irrigado com água residuária da suinocultura. Revista Brasileira de Engenharia Agricola e Ambiental, v.14, n.7, p.692-697, 2010.

CHENG, C. Y.; CHU, L. M. Fate and distribution of nitrogen in soil and plants irrigated with landfill leachate. Waste Management. v. 31, p. 1239-1249. 2011.

COELHO, A. M. Manejo da adubação nitrogenada da cultura do milho. Circular Técnica, Embrapa, n.96, 2007.

CONAMA - Conselho Nacional do Meio Ambiente (2005). Resolução nº 357, de 17 de março de 2005. Ministério do Meio Ambiente.

CONAMA - Conselho Nacional do Meio Ambiente (2008). Resolução n 396, de 3 de Abril de 2008. Ministério do Meio Ambiente.

CORRÊA, J. C; BÜLL, L. T.; CRUSCIOL, C. A. C.; MARCELINO, R.; MAUAD, M. Correção da acidez e mobilidade de íons em Latossolo com aplicação superficial de escória, lama cal, lodos de esgoto e 
calcário. Pesquisa Agropecuária. Brasileira, v.42, n.9, p.13071317, 2007.

DONAGEMMA, G. K. ; RUIZ, H. A.; ALVAREZ, V. H.; FERREIRA, P. A.; CANTARUTTI, R. B.; SILVA, A. T.; FIGUEIREDO, G. C. Distribuição do amônio, nitrato, potássio e fósforo em colunas de Latossolos fertirrigadas. Revista Brasileira Ciência do Solo, v. 32, p. 2493-2504, 2008.

EMPRESA BRASILEIRA DE PESQUISA AGROPECUÁRIA-EMBRAPA. Serviço Nacional de Levantamento e Conservação de Solos. Manual de métodos e análises de solos. 2 ed. Rio de Janeiro, 1997.

EMPRESA BRASILEIRA DE PESQUISA AGROPECUÁRIA-EMBRAPA. Manual de análises químicas de solos, plantas e fertilizantes. Brasília, 2011.

FERREIRA, P.A; GARCIA, G. O.; MATOS, A. T.; RUIZ, H. A.; JUNIOR J. C. F. B. Transporte no solo de solutos presentes na água residuária de café conilon. Acta Scientiarum Agronomy. v. 28, n. 1, p. 29-35, 2006.

Freitas, W. da S.; Oliveira, R. A. de; Pinto, F. A.; Cecon, P. R.; GALVÃO, J. C. C. Efeito da Aplicação de águas residuárias de suinocultura sobre a produção do milho silagem. Revista Brasileira de Engenharia Agricola e Ambiental. V. 8, n. 1, p. 120-125, 2004.

GOMES, E. R. S.; SAMPAIO, S. C.; CORREAA, M. M.; VILAS BOAS, M. A.; ALVES, L. F. A.; SOBRINHO, T. A. Movimento de nitrato proveniente de água residuária em colunas de solo. Engenharia Agrícola, v.24, n.3, 2004.

IAPAR. Instituto Agronômico do Paraná. Médias históricas em estações do LAPAR. Disponível em: $<$ http://www.iapar.pr.gov.br/arquivos/Image/monito ramento/Medias_Historicas/Francisco_Beltrao.htm>. Acesso em: 13 mar. 2016a.

IAPAR. Médias históricas em estações do IAPAR. Disponível em: <http://www.iapar.pr.gov.br/arquivos/Image/monito ramento/Medias_Historicas/Pato_Branco.htm>.

Acesso em: 13 mar. 2016b.

IBGE, Instituto Brasileiro de Geografia e Estatística. Produção da pecuária municipal. V. 42, 2014.

LUCHESE, A. V.; DA COSTA, A. C. S.; JÚNIOR, I. G. S. Lixiviação de íons após a aplicação de resíduos orgânicos de uma indústria farmoquímica. Revista Brasileira de Engenharia Agrícola e Ambiental, v.12, n.2, p.189-199, 2008.

LUNA, N. R. S.; ANDRADE, E. M.; CRISÓSTOMO, L. A.; MEIRELES, A. C. M.; AQUINO, D. N. Dinâmica do nitrato e cloreto no solo e a qualidade das águas subterrâneas do distrito de irrigação Baixo Acaraú,
CE. RevistaAgro@mbiente On-line, v. 7, n. 1, p. 53-62, 2013.

MALAVOLTA, E.; VITTI, G.C; de OLIVEIRA, S.A. Avaliação do estado nutricional das plantas: princípios e aplicações. Piracicaba: Potafos, 1997.

MENEGAZ, R. C; BACCARIN, L. I. P.; HEMKEMEIER , M. ; BACCARIN, S. D.; DEROSSI , A.; DECESARO , A.; FABRIS, E. Remoção Físicoquímica de Fósforo por Floco-sedimentação Aplicada ao Pós-tratamento de Efluente de Abatedouro Avícola. Revista Ciências Exatas e Naturais, v.13, n 2, p. 228-255, 2011.

MINISTÉRIO DA SAÚDE (2011). Portaria $n^{\circ} 2.914$, de 12 de dezembro de 2011.

PINTO, L. A. M; PINTO, M. M.; BOVO, J. ; MATEUS, G. A. P.; TAVARES , F. O.; BAPTISTA, A. T. A. ; HIRATA, A. K. Aspectos ambientais do abate de aves: Uma revisão. Revista UNINGÁ Review, v. 22, n.3, p. 44-50, 2015.

SAMPAIO, S. C.; CAOVILLA, F. A.; OPAZO, M. A. U.; Nóbrega, L. H. P.; Suszek, M.; Smanhotto, A. Lixiviação de íons em colunas de solo deformado e indeformado. Revista Engenharia Agrícola, v.30, n.1, p. 150-159, 2010.

SANTOS, J. S.; LIMA, V. L. A.; JÚNIOR, J. C. F. B. SILVA, B. D.; AZEVEDO, C. A. V. Mobilidade de solutos em colunas de solo com água residuária doméstica e de suinocultura. Revista Brasileira de Engenharia Agrícola e Ambiental. v.14, n.11, p. 12261233, 2010.

SILVA, M. A. S.; GRIEBELER, N. P.; BORGES, L. C. Uso de vinhaça e impactos nas propriedades do solo e lençol freático. Revista Brasileira de Engenharia Agrícola e Ambiental, v.11, n.1, p.108-114, 2007.

SPOSITO, G. The chemistry of soils. 2.ed. Oxford: Oxford University Press, 2008.

WHO-World Health Organization. Guidelines for drinking-water quality. 4 ed, 518 p. Suíça, 2011. 